\title{
THE SOCIAL ENTERPRISE AS AN ALTERNATIVE ECONOMIC MODEL FOR SMALL AND MEDIUM-SIZED ENTERPRISES. EXAMPLES OF SUCCESSFUL SOCIAL ENTERPRISES
}

\author{
G. Zheliazkov, K. Stoyanov* \\ Industrial Business and Entrepreneurship Department, Trakia University, Stara Zagora, Bulgaria
}

\begin{abstract}
The impact of social economy is constantly growing across the European Union. Especially in time of economic crisis that is somehow reluctant to turn into economic growth in most of the member states. More and more entrepreneurs are willing to explore opportunities of social economy driven by their entrepreneurial mindset and the gap created by the lack of public financing for different types of social services traditionally covered by state budget. As Bulgarian legislation is still tarring to introduce social economy and social enterprise into its framework, this article pinpoints some successful examples of social enterprises operating in different economic fields and in different member states of the European Union. By presenting those alternative models for development of small and medium-sized enterprises (SMEs), authors emphasize on key moments that led those companies to success.
\end{abstract}

Key words:_Social Enterprise, Social Economy, Entrepreneurship

Social entrepreneurship is the recognition of a social problem and the use of entrepreneurial principles to organise, create and manage a social venture to achieve a desired social change. While a business entrepreneur typically measures performance in profit and return, a social entrepreneur also measures positive returns to society. Thus, the main aim of social entrepreneurship is to further broaden social, cultural, and environmental goals. Social entrepreneurs are commonly associated with the voluntary and not-for-profit sectors, but this need not preclude making a profit.

In social enterprises, entrepreneurial behavior is combined with the desire to use the market as a means of meeting social needs serving the general interest and the common good for the benefit of the community.

Enhancing social enterprises and promoting their development can lead to short- and long-term

*Correspondence to: Konstantin Stoyanov, 75B, Gen. Gurko str., fl. 2, ap. 13, 6000 Stara Zagora, Bulgaria, Tel: +359 886 845757, e-mail: stoyanov.konstantin@gmail.com benefits for public budgets by reducing public spending and increasing tax revenues compared with other methods of addressing social needs. Social enterprises can often be more effective in fulfilling community goals in comparison with other actors from the purely private or purely public sector because they know local needs and have a pronounced social mission.

The launch of the social enterprise is accompanied not only by all the challenges that have to face any entrepreneur, but also those arising from the social dimension. This can be compounded by adverse conditions characterized by a lack of understanding of binary economic and social nature of social enterprises.

The introduction of policies that provide ecofriendly system for social enterprises, not only in startup stage but beyond is crucial that these businesses will realize their potential.Policies should focus on promoting social entrepreneurship, creating legal, regulatory and fiscal frameworks, providing sustainable financing of services for business development and support structures for market access and further research in the sector. 
Example of Social Enterprise in a social business friendly environment

Generally, social enterprises have an entrepreneurial approach and pursue social mission. They may have limited focus on earnings (or be non-profit) and may have different management systems. „Juratri” in France is an example of very successful social enterprise that combines the mission of providing goods and services to the market, while reintegrating vulnerable people in the labor market. An economic model favored by the mixed stream of financial revenue, combined with vision and dynamism, which itself becomes a key element for striking development.

Founded in 1993 as a limited liability company in Lons-le-Saunier, „Juratri” became a cooperative in December 2006 Since its inception, the focus is on the development of the process of social and professional integration of persons excluded from the labor market by economic project related to sorting waste (municipal and industrial waste and electrical and electronic equipment waste).

„Juratri” turnover was 6,158,913 EUR in 2011, an increase of $15 \%$ compared to 2010 and $190 \%$ by 2006 . The company employs 135 people and created 53 of these jobs in the past five years. 63 persons are in the "integration process", which is working on fixed-term contract of integration and are provided with close supervision and mentoring. Such contracts are designed to facilitate the integration of unemployed persons who face difficulties entering the labor market. In 2011 ,Juratri” aimed to support those who have no formal qualifications, have unstable housing situations, are young people and those receiving social benefits.

„Juratri” success in job creation and support of working integration activities is rooted not only in their expertise and involvement in a stable sector, but also in the wider public policy measures that support elements of its activities.

In France, integration through economic activity is enshrined in the Labour Code and the Law on combating exclusion since 1998. It provides a framework for social economy organizations. According to the act from 1998, an agreement between the companies in the field of the social economy and the state, stating, among other things, the number of workplaces created for social needs is likely to be supported by a public agency. For each workplace with integration purpose, the company is rewarded 9681 EUR per year from the state. Employees benefiting from such programs must be registered at the Labour Office. In 2012, 62 positions were funded following this procedure.

„Juratri” is also supported on regional level for training employees involved in the integration process. The amount received is 3000 EUR per workplace.

In 2012 ,Juratri” invests over 2 million EUR to position itself as a leader in recycling industry, with highly innovative and effective infrastructure."Juratri" finance this investment with its own funds $(65 \%)$ and grants (35\%) coming from the General Council, Regional Council, ADEME (French Agency for the Management of Energy and Environment) and the European Regional Development Fund (ERDF). This fairly economic approach is something not specific to social economy organizations, but reflects the potential that those type of enterprises could present if they have the necessary conditions and state support.

\section{Example of Social Enterprise in a social business un-friendly environment}

"Motivation Romania" highlights how social enterprise can adapt to the underdeveloped regulatory environment through appropriate solutions. "Motivation Foundation Romania" has focused its main activities towards people with disabilities. It gets more than half of its funding from the European Social Fund, and also receives support from charities, trusts and private sector.The Foundation has also launched a social enterprise "Motivation" SRL, which makes wheelchairs to support long-term sustainability of the organization. "Motivation" SRL as a social enterprise is closely linked to changes in the general framework of the Romanian market of medical equipment. In 2001, new laws liberalised the market and enabled a wider range of companies to be accredited by the National Health Insurance Company, to be producers of mobility equipment. At the same time, the Romanian government adopted new laws allowing sheltered workshops to receive funds from the National Health Insurance Fund, if they can provide a proof of accreditation by the National Health insurance Company and registered as independent non-for-profit companies. However, in Romania there is only a common legal framework which applies to civil society organizations and to private companies. This specific trait penalises commercial activities undertaken by the social enterprise. So "Motivation" SRL is not exempt from taxes and 
pay all taxes applicable to Romanian companies, including VAT of $19 \%$; income tax rate of $16 \%$; tax on dividends distributed to shareholders, where the percentage is $10 \%$ for legal entities and $16 \%$ for individual shareholders; and taxes on employment, including income tax, social security, unemployment, etc.

$30 \%$ of its employees are people with disabilities. Therefore "Motivation" SRL is certified as by the National Authority for People with Disabilities as a sheltered workshop. In 2012 the Foundation has 102 employees (12 disabled persons) and its social enterprise - the SRL - 27 employees (8 persons).

"Motivation" SRL has received the following economic results:

- $\quad$ sales growth of nearly $600 \%$ from 2002 to 2006 ;

- $\quad$ profit of 123000 EUR for the year 2011, which is twice more than the profit from the previous year

\section{Other uncommon examples of Social Enterprises support}

The support for social economy coming from revisited models of traditional business incubators could be an option but it had to be generously prepared. Such is the case of NESsT which supports social enterprises at all stages of development and operates in 10 countries around the world, including Croatia, Czech Republic, Hungary, Romania and Slovakia. It provides financial support, alongside training and mentoring services, for social enterprises at prestart-up and start-up stages, as well as on-going support, including for expansion. NESsT was founded in 1997 as a non-profit organisation in order to promote social entrepreneurship. It has developed a multi-step 'portfolio process' where each step builds upon the previous one, and progression is based on the achievement of certain goals. The portfolio process covers planning, incubation and scaling up.

The process is rigorous and focuses on developing successful social enterprises. In the 2009-2010 Social Enterprise Competitions, 50 applicants received initial training, of which 22 went onto complete business plans and 11 moved into the incubation phase. The 2010 impact report following all NESsT social enterprises noted that the enterprises, on average, had increased their income by $39 \%$, employed 24 people permanently, and, where the focus was on jobs, had increased their employment by $23 \%$.
Another interesting form of supportive organization operates in Spain. This is the Social Innovation Park, managed by the Basque Centre for Social and Corporate Innovation, Denokinn, which is owned by local authorities around the Bilbao area, the Park was established with the aim of creating employment opportunities in an area of decline. The Park provides a place where individuals, social economy organisations, charities, NGOs, the private sector and institutions can meet to seek to create new products and services leading to new job creation. The Park hosts a range of facilities for the generation of new social enterprises, which can then receive support from the incubator services (training, mentoring, etc.) provided, and a 'Social Innovation Academy' which provides training for social economy.

\section{General Findings}

Social enterprises need business support. However, a universal approach to support business which expects social enterprises to require the same services as traditional commercial enterprises is not likely to be adapted. This is due to the fact that the elaborated approach should take into account the social dimension as main reason for the creation of social enterprises. Indeed the supply of information, advice, counseling and so on have to follow this model. Engaging with social enterprises and other social economy organizations involved in providing such support, can also be useful to promote social entrepreneurship and development in general.

Without such support structures there is a risk that social enterprises will thrive only in certain territorial niches or sectors of activity. However, existing support structures for the sector of social enterprises are not evenly distributed, but tend to be concentrated in those areas and sectors where social enterprises have already established their presence and have strong integration capacity. Therefore, to avoid the opposite effect, when supporting structures actually aggravate the uneven development of social enterprises, there should be put important efforts to transfer and disseminate examples of good practice from other areas.

\section{CONCLUSIONS}

Social entrepreneurship is increasingly challenging the traditional idea of doing business only fro the profit and social enterprises to develop around the world, even if in a statistical sense, they still form a niche business. Social 
enterprises contribute to help keep the people at risk of social exclusion attached to the labor market by providing training and integration activities. They also address the social needs of groups that government agencies may have difficulties to reach.

Social enterprises are not immune from the impact of the economic crisis that Europe is facing and politicians should not believe that social enterprises can fill all the gaps in the provision of services that austerity has brought, or create all needed to overcome jobs crisis workplaces. Social enterprises are not an universal answer to social and economic challenges that arises in modern societies. However, social economy is an important tool for tackling those challenges.

Their contribution can be increased by policies that favor their growth and the efficiency of the sector in general. The focus of those policies should be on providing the right environment in which social enterprises can thrive, as well as activities to promote social entrepreneurship and improve the legal and regulatory framework, financing, access to markets, services for business development and support structures, training and research. It is important that governments take a cross-border approach in policy development and adopt a systematic approach to increase the capacity of social enterprises to contribute more effectively to social inclusion and inclusive growth

\section{REFERENCES}

1. Borzaga, C., Defourny, J. (eds) The Emergence of Social Enterprise, London and New York: Routledge, 2001.

2. Cafaggi, F. and P. Iamiceli, "New Frontiers in the Legal Structure and Legislation of Social Enterprises in Europe: A Comparative Analysis", in A. Noya (ed.), The Changing Boundaries of Social Enterprises, OECD, Paris, 2009.

3. CIRIEC, The Social economy in the European Union, $\mathrm{N}^{\circ}$. CESE/contract CES 18.106 - 2012, The European Economic and Social Committee (EESC), 2012.

4. Communication from the Commission to the European Parliament, The Council, The European Economic and Social Committee and The Committee of the Regions, Social Business Initiative Creating a favourable climate for social enterprises, key stakeholders in the social economy and innovation Brussels, 25.10.2011 $\operatorname{COM}(2011) 682$ final., 2011
5. Daniele, D., T. Johnson and F. Zandonai, "Networks as Support structures for Social Enterprises" in A. Noya (ed.), The Changing Boundaries of Social Enterprises, OECD, Paris, 2009

6. Defourny J., Nyssens M., Social Enterprise In Europe: Recent Trends And Developments, 2001.

7. Leś, E. and M. Kolin, "East-Central Europe", in J. A. Kerlin (ed.), Social Enterprise: A Global Comparison, Tufts University Press, London, 2012

8. MOUVES (Mouvement des entrepreneurs sociaux) Le livre blanc des entrepreneurs sociaux. L'efficacité économique au service de l'intérêt général, Editions Rue de l'échiquier, 2012

9. Mendell, M. and R. Nogales, "Social Enterprises in OECD Member Countries: What are the Financial Streams?", in A. Noya (ed.), The Changing Boundaries of Social Enterprises, OECD, Paris, 2009.

10. Mendell, M., Improving social inclusion at the local level through the social economy: designing an enabling policy framework, OECD CFE/LEED (2010)13, 2010.

11.Nagler, J., The Importance of Social Entrepreneurship for Development, 2007

12. Noya, A. and E. Clarence (eds.), The Social Economy: Building Inclusive Economies, OECD, Paris, 2007.

13. Nyssens, M., "Western Europe", in J.A. Kerlin (ed.), Social Enterprise: A Global Comparison, Tufts University Press, Hanover/London, 2012.

14.OECD, Entrepreneurship, SMEs and Innovation, OECD, Paris, 2010.

15. OECD, Policy Brief on Social Entrepreneurship Entrepreneurial. Activities in Europe, OECD, Luxembourg, 2013

16. OECD, Social Enterprises, OECD, Paris, 1999.

17.Perista, H. \& Nogueira, S., National Profiles of Work Integration Social Enterprises in Portugal, Working Papers Series, 02/09, Liege: EMES European Research Network, 2002

18. Skoll Centre for Social Entrepreneurship, University of Oxford (2009): Saïd Business School, <http://www.sbs.ox.ac.uk/centres/skoll/Pages/d efault.aspx $>$, viewed 10 September 2012

19. Terjesen, S., J. Lepoutre, R. Justo and N. Bosma, Global Entrepreneurship Monitor Report on Social Entrepreneurship, 2011.

20. The World Bank, Social Capital, <http://www.worldbank.org/>, viewed 29 October 2012

21. Varbanova L., LabforCulture.org, Social Entrepreneurship, October 2009 